\title{
The influence of duration of the distillation of fresh and dried flowers on the essential oil composition of lavandin cultivated in Republic of Macedonia
}

\author{
Marija Karapandzova*, Ivana Cvetkovikj, Gjoshe Stefkov, Vlatko Stoimenov, \\ Martin Crvenov, Svetlana Kulevanova
}

Institute of Pharmacognosy, Faculty of Pharmacy, University “Ss Cyril and Methodius”, Skopje, Republic of Macedonia

Received: October 2012, Accepted: November 2012

\begin{abstract}
The main objective of this study was to analyze the essential oil composition of cultivated lavandin (Lavandula $x$ intermedia Emeric ex Loisel., Lamiaceae) from Republic of Macedonia and to evaluate the influence of the drying time of plant material and the distillation duration on the oil composition. Four different essential oils were obtained by hydrodistillation in a Clevenger type apparatus from freshly harvested and air dried flowers of lavandin and varying in distillation time (30 min and $2 \mathrm{~h}$ ). Fifty-six compounds were identified by GC/ FID/MS representing $96.57 \%$ to $98.23 \%$ of the total oil. Prevailing constituents in all tested oils were linalool, borneol and terpinene-4-ol, present in amounts from 35.23 to $42.24 \%, 12.28$ to $16.68 \%$ and 4.44 to $5.62 \%$, respectively. The content of 1,8-cineole varied from $3.99 \%$ to $8.42 \%$ while that of camphor was between $5.96 \%$ and $7.04 \%$. Linalyl acetate was present in amounts from $1.26 \%$ to $3.21 \%$. Unexpectedly, the duration of distillation insignificantly influenced the essential oil composition. Few differences, mainly in the content of borneol $(13.71 \%$ and $16.68 \%$ in the oil from fresh and dried flowers, respectively) were recorded in the essential oils obtained by 30 minutes distillation, while the content of the other constituents was almost unchanged. However, the isolated essential oils of lavandin did not comply with the international standards requirements for the lavandin essential oil composition.
\end{abstract}

Key wards: Lavandula intermedia, Lamiaceae, GC/FID/MS, duration of hydrodistillation, drying time

\section{Introduction}

Medicinally and commercially important Lavandula species are perennial shrubs growing in rocky and calcareous areas in Mediterranean basin. For commercial production of essential oil, three species are used: L. angustifolia Mill. (common or English lavender), L. latifolia Medik. (spike lavender) and L. angustifolia $x$ L. latifolia (L. $x$ intermedia Emeric ex Loisel.) known as lavandin. There are also several cultivars that are planted for commercial production of essential oils with similar features to lavandin, such as: Grappenhall, Provence, Grosso, Dutch

\footnotetext{
* marija karapandzova@ff.ukim.edu.mk
}

Mill, Abrial and Seal (lavender production, http://www. nda.agric.za/docs/brochures/essoilslavender.pdf).

Lavender flowers and oil are often used in the households as an herbal remedy for nervous disturbance and flatulence while externally are used to cure nervous headache (Gamez et al., 1990), anxiety and mild depression (Lewis \& Kowalski, 2002; Lenrner et al., 2005). The essential oil act with powerful antimicrobial properties (Sabara and $\mathrm{Ku}$ nicka-Styczynska, 2009) and is useful in the treatment of burns, sunburns, scalds, bites, vaginal discharge and anal fissure (Shafaghat et al., 2012). It is also known as antioxidant (Economou et al., 1991), antispasmodic (Cavanagh and Wilkinson, 2002), aromatic, carminative, cholagoge, diuretic, nervine, sedative, stimulative, stomachic and tonic (Lis-Balchin and Hart, 1999; Gilani et al., 2000; 
Kalemba and Kunicka, 2003). It is used in aromatherapy as well (Sabara and Kunicka-Styczynska, 2009). Industrial application of lavender oil include production of high-quality perfumes, candles, incense sachets, potpourri, wands, pillows, flower bundles, dried arrangements, wall hangings, wreaths and (Pauls et al., 2004) is used in bath products such as soap, shampoo, bath oil, lotion and bath salt. Owing to its safety and sedative action it is incorporated extensively in cosmetic preparations (Azar et al., 2011). In food manufacturing it is added in flavoring beverages, ice-creams, candy, baked goods and chewing gum (Kim and Lee, 2002, Wogiatzi et al., 2011).

The world's production of Lavandula species is mainly directed to lavandin cultivars, which have more vigorous growth and give greater amounts of essential oil. The average annual production of lavandin essential oil riches 1200 tons traditionally produced in Europe and United States (Peterson, 2002). On the other hand, the world production of lavender (L. angustifolia) oil is only 200 tons per annum, predominantly emanating out of Europe (Peterson, 2002). It is well known that chemical composition of the essential oils of lavender and lavandin largely depend on the species from which it is obtained (Kustrak and Besic, 1975; Wogiatzi et al., 2011). Key differences in the composition of these oils is the low amount of camphor (less than 1\%) and the absence of bornyl acetate in lavender (L. angustifolia) oil, while lavandin (L. intermedia) oil contains camphor between $10-12 \%$ and linalool up to $20 \%$ (Peterson, 2002).

The characteristic odor of lavender oil originates from the presence of linalyl acetate and according to the regulations lavender oil should not contain less than $25 \%$ of this constituent. Additionally, the content of 1,8-cineole should be less than $2.5 \%$ (Ph. Eur. 7). On the other hand, the content of these components in lavandin essential oil varies a lot depending on the characteristics of the cultivars and other factors (Wogiatzi et al., 2011).

Lavender oil can be easily isolated from the flower heads using steam distillation. The time of distillation influences the essential oil composition and its quality. If distillation time is too short, compounds with higher boiling point may be missing from the oil. When the time of distillation is too long, the oil may have unpleasant smell. According some authors, nearly $75 \%$ of the total yield comes in the first 25 minutes of distillation and gives a commercial grade of lavender oil (Pitman, 2004). Even the steam distillation is still the most preferable technique of oil isolation, during this process, molecular rearrangements, hydratation of double bonds and hydrolyzis of esters to alcohols and carboxylic acids can occur. In high-quality lavender oil the ratio between linalyl acetate and linalool should be higher than one (Porter et al., 1982; Wesolowska et al., 2010). Linalool poses sweet odor and linalyl acetate refreshing one, appreciated in many applications (Wesolowska et al., 2010). Nowadays, commercially produced lavender oil is often distilled for only 15 minutes at a very high temperature and under very high pressure (Wesolowska et al., 2010). Because of its poor quality, synthetic linalyl acetate is often added in order to make it smell like the genuine plant fragrance (Sell, 2006; Wesolowska et al., 2010).

Within the one Lavandula species, the essential oil composition differs significantly depending on where and under what condition the plant was grown (Guillen et al., 1996). Other variations in essential oil composition may occur depending on duration, temperature and pressure of distillation (Wesolowska et al., 2010). Therefore, the aim of the present study was to evaluate the influence of distillation time on the composition of lavandin (L. $x$ intermedia) essential oil as well as to determine the differences in chemical composition of the oils isolated from fresh or dried flowers of lavandin cultivated in Republic of Macedonia. Obtained results will be evaluated according to different standards requirements.

\section{Material and methods}

\section{Plant material}

Flowering tops of cultivated lavandin were collected in a full blooming of plants during the summer 2012. A voucher specimen of the plant was deposited at the Herbarium of the Institute of Pharmacognosy and Pharmaceutical Botany at the Faculty of Pharmacy in Skopje, Republic of Macedonia (No. LI-01/012). Proper amount of freshly collected material was distilled during the same day and the rest was put on a paper sheets in a shade and left to air drying. Dried flowers were also used for isolation of essential oil.

\section{Essential oil isolation}

Essential oils were isolated by hydrodistillation in a Clevenger-type apparatus following the procedure from European Pharmacopeia (Ph. Eur. 7). Four different essential oils were isolated from fresh and dried flowers of lavandin, by distillation lasting $30 \mathrm{~min}$ and $2 \mathrm{hrs}$. The obtained oils were dried over anhydrous sodium sulfate and stored in refrigerator until analysis. Two repetition of distillation were performed.

\section{GC/FID/MS analysis}

Essential oil samples were analyzed on Agilent 7890A Gas Chromatography system equipped with flame ionization detector (FID) and Agilent 5975C mass spectrometer (MS) equipped with capillary flow technology which enables simultaneous analysis of the sample on both detectors. HP-5MS (30 m x $0.25 \mathrm{~mm}$, film thickness $0.25 \mu \mathrm{m}$ ) capillary column was used. Operating conditions were as follows: oven temperature $60{ }^{\circ} \mathrm{C}(5 \mathrm{~min}), 1{ }^{\circ} \mathrm{C} / \mathrm{min}$ to 80 ${ }^{\circ} \mathrm{C}(2 \mathrm{~min})$ and $5{ }^{\circ} \mathrm{C} / \mathrm{min}$ to $280{ }^{\circ} \mathrm{C}(5 \mathrm{~min})$; flow rate of $1 \mathrm{ml} / \mathrm{min}(\mathrm{He})$; injector $\mathrm{T}=260{ }^{\circ} \mathrm{C}$; FID $\mathrm{T}=270{ }^{\circ} \mathrm{C}$; $1 \mu \mathrm{l}$ injection volume at split ratio $1: 1$. 
The mass spectrometry conditions were: ionization energy $70 \mathrm{eV}$, ion source temperature $230{ }^{\circ} \mathrm{C}$, transfer line temperature $280{ }^{\circ} \mathrm{C}$ and mass range from $50-500$ Da. The MS was operated in scan mode. Identification of the components present in essential oils was made by comparing mass spectra of components in essential oils with those from NIST, Wiley and Adams mass spectra libraries, by AMDIS (Automated Mass Spectral Deconvolution and Identification System) and by comparing literature and estimated Kovat's (retention) indices that were determined using mixture of homologous series of normal alkanes from $\mathrm{C}_{9}$ to $\mathrm{C}_{25}$ in hexane, under the same above mentioned conditions.

The percentage ratio of essential oils components was computed by the normalization method of the GC/FID peak areas and average values were taken into further consideration $(n=3)$.

\section{Results and discussion}

The results of GC/FID/MS analysis of the essential oils, isolated from fresh and dried flowers of lavandin, obtained either by hydrodistillation of 30 minutes or 2 hours duration, are presented in Table 1. Total of fifty-six compounds were identified in the analyzed samples of lavandin representing $96.57 \%$ to $98.23 \%$ of the total oil. The most abundant compound in the analyzed essential oils was lina- lool ( 35.23 to $42.24 \%$ ), followed by borneol and terpinene4-ol, presented in amounts from $12.28 \%$ to $16.68 \%$ and from $4.44 \%$ to $5.62 \%$, respectively. The content of 1,8 -cineole varied from $3.99 \%$ to $8.42 \%$ and that of camphor between $5.96 \%$ and $7.04 \%$. In all tested samples of lavandin oil the content of linalyl acetate was very low, presented in amounts from $1.26 \%$ to $3.21 \%$. Similar quantities of lavandulyl acetate were determined (1.53-2.42\%).

From the presented results a smaller decrease in the content of linalool can be noticed when prolonged distillation procedure was applied $(38.58 \%)$ compared to the 30 minutes distillation procedure $(40.13 \%)$. Similar trend of decreasing was noticed in the abundance of almost all other dominant compounds. For instance camphor amount decreased from $6.62 \%$ to $5.96 \%$, borneol from $13.71 \%$ to $12.28 \%$ and terpinene-4-ol from $5.62 \%$ to $5.24 \%$. The 2 hrs hydrodistillation increased the amount of 1,8-cineole (from $7.17 \%$ to $7.39 \%$ ), cis- $\beta$-ocimene (from $2.45 \%$ to $2.54 \%$ ) and trans- $\beta$-ocimene (from $0.78 \%$ to $0.85 \%$ ) (Table 1). Increased content after prolonged distillation of fresh flowers was also notice in eugenol (from $0.00 \%$ to $1.89 \%$ ) and eugenol acetate (from $0.04 \%$ to $3.05 \%$ ). Also, few other esterified monoterpene compounds were identified in very small quantities, linalyl and lavandulyl acetate, followed by bornyl, neryl and geranyl acetate and lavandulyl isovalerate. After all, essential oils obtained from fresh flowers by 30 minutes and 2 hours lasting distillation pro-

Table 1. Chemical composition of the essential oils isolated from lavandin (\%)

\begin{tabular}{|c|c|c|c|c|c|c|c|}
\hline \multirow[b]{2}{*}{ No. } & \multirow[b]{2}{*}{ KIL } & \multirow[b]{2}{*}{ KIE } & \multirow[b]{2}{*}{ Components } & \multicolumn{2}{|c|}{ Fresh flowers } & \multicolumn{2}{|c|}{ Dried flowers } \\
\hline & & & & $2 \mathrm{~h}$ & $30 \mathrm{~min}$. & $2 \mathrm{~h}$ & $30 \mathrm{~min}$. \\
\hline 1 & 931 & 940.3 & $\alpha$-Thujene & - & $\operatorname{tr}$ & - & - \\
\hline 2 & 939 & 944.2 & $\alpha$-Pinene & 0.21 & 0.18 & 0.30 & - \\
\hline 3 & 953 & 953.7 & Camphene & 0.50 & 0.50 & 0.56 & - \\
\hline 4 & 975 & 970.7 & Sabinene & 0.11 & 0.12 & 0.15 & - \\
\hline 5 & 980 & 972.8 & $\beta$-Pinene & 0.24 & 0.20 & 0.26 & 0.46 \\
\hline 6 & 991 & 984.4 & Myrcene & 1.01 & 0.93 & 1.09 & $\operatorname{tr}$ \\
\hline 7 & 1007 & 999.1 & $\Delta^{3}$-Carene & 0.27 & 0.23 & 0.34 & - \\
\hline 8 & 1018 & 1004.8 & $\alpha$-Terpinene & $\operatorname{tr}$ & - & - & - \\
\hline 9 & 1025 & 1011.9 & $p$-Cymene & 0.13 & 0.06 & 0.12 & - \\
\hline 10 & 1031 & 1015.5 & $\beta$-Phellandrene & 3.84 & 3.64 & 4.41 & 1.16 \\
\hline 11 & 1033 & 1017.2 & 1,8-Cineole & 7.39 & 7.17 & 8.42 & 3.99 \\
\hline 12 & 1040 & 1025.4 & cis- $\beta$-Ocimene & 2.54 & 2.45 & 3.15 & 1.17 \\
\hline 13 & 1050 & 1035.1 & trans- $\beta$-Ocimene & 0.85 & 0.78 & 1.11 & 0.42 \\
\hline 14 & 1062 & 1044.1 & $\gamma$-Terpinene & 0.20 & 0.15 & 0.25 & 0.13 \\
\hline 15 & 1088 & 1073.5 & $\alpha$-Terpinolene & 0.45 & 0.43 & 0.52 & 0.26 \\
\hline 16 & 1098 & 1091.8 & Linalool & 38.58 & 40.13 & 35.23 & 42.24 \\
\hline 17 & 1142 & 1125.7 & neo-allo-Ocimene & 0.87 & 0.64 & 0.87 & - \\
\hline
\end{tabular}




\begin{tabular}{|c|c|c|c|c|c|c|c|}
\hline & & & & & vers & Drie & vers \\
\hline No. & KIL & KIE & Components & $2 \mathrm{~h}$ & $30 \mathrm{~min}$. & $2 \mathrm{~h}$ & $30 \mathrm{~min}$. \\
\hline 18 & 1143 & 1139.2 & Camphor & 5.96 & 6.62 & 6.84 & 7.04 \\
\hline 19 & 1150 & 1150.0 & Hexyl isobutyrate & $\operatorname{tr}$ & 0.07 & - & - \\
\hline 20 & 1162 & 1159.3 & Pinocarvone & - & - & 0.09 & 0.11 \\
\hline 21 & 1165 & 1162.9 & Borneol & 12.28 & 13.71 & 13.77 & 16.68 \\
\hline 22 & 1166 & 1166.2 & Lavandulol & 1.65 & 1.70 & 1.52 & 1.93 \\
\hline 23 & 1177 & 1172.5 & Terpinene-4-ol & 5.24 & 5.62 & 4.44 & 5.25 \\
\hline 24 & 1183 & 1180.0 & $p$-Cymene-8-ol & $\operatorname{tr}$ & - & $\operatorname{tr}$ & $\operatorname{tr}$ \\
\hline 25 & 1189 & 1183.3 & $\alpha$-Terpineol & 1.24 & 1.25 & 1.35 & 1.35 \\
\hline 26 & 1191 & 1186.8 & Hexyl butyrate & 0.48 & 0.55 & 0.46 & 0.59 \\
\hline 27 & 1193 & 1195.9 & $c i s$-Piperitol & $\operatorname{tr}$ & 0.05 & 0.08 & 0.10 \\
\hline 28 & 1212 & 1205.7 & trans-Carveol & $\operatorname{tr}$ & $\operatorname{tr}$ & 0.11 & 0.06 \\
\hline 29 & 1228 & 1217.7 & Nerol & 0.15 & 0.12 & 0.16 & 0.14 \\
\hline 30 & 1239 & 1227.2 & Cumic aldehyde & 0.29 & 0.33 & 0.42 & 0.46 \\
\hline 31 & 1243 & 1232.7 & Carvone & 0.14 & 0.20 & 0.25 & 0.29 \\
\hline 32 & 1256 & 1245.7 & Linalyl acetate & 1.26 & 2.18 & 1.86 & 3.21 \\
\hline 33 & 1285 & 1272.7 & Bornyl acetate & 0.07 & 0.07 & 0.09 & 0.11 \\
\hline 34 & 1289 & 1278.5 & Lavandulyl acetate & 1.53 & 1.64 & 1.84 & 2.42 \\
\hline 35 & 1290 & 1290.9 & Thymol & $\operatorname{tr}$ & - & - & - \\
\hline 36 & 1331 & 1314.6 & Hexyl tiglate & 0.03 & 0.05 & 0.06 & 0.06 \\
\hline 37 & 1356 & 1341.6 & Eugenol & 1.89 & - & - & - \\
\hline 38 & 1365 & 1348.0 & Neryl acetate & 0.38 & 0.18 & 0.26 & 0.24 \\
\hline 39 & 1380 & 1362.9 & Daucene & 0.05 & 0.06 & 0.07 & 0.08 \\
\hline 40 & 1383 & 1366.3 & Geranyl acetate & 0.40 & 0.32 & 0.40 & 0.39 \\
\hline 41 & 1409 & 1390.4 & $\alpha$-Gurjunene & $\operatorname{tr}$ & 0.03 & 0.03 & 0.05 \\
\hline 42 & 1418 & 1399.6 & trans-Caryophyllene & 0.39 & 0.48 & 0.63 & 0.67 \\
\hline 43 & 1458 & 1435.4 & trans- $\beta$-Farnesene & 1.18 & 1.60 & 2.08 & 2.21 \\
\hline 44 & 1477 & 1450.4 & $\gamma$-Muurolene & 0.04 & 0.06 & 0.08 & 0.08 \\
\hline 45 & 1480 & 1462.5 & Germacrene D & 0.08 & 0.09 & 0.12 & 0.12 \\
\hline 46 & 1510 & 1486.0 & Lavandulyl isovalerate & 0.49 & 0.61 & 0.75 & 0.80 \\
\hline 47 & 1513 & 1493.6 & $\gamma$-Cadinene & 0.04 & 0.06 & 0.10 & 0.09 \\
\hline 48 & 1524 & 1501.7 & $\delta$-Cadinene & $\operatorname{tr}$ & $\operatorname{tr}$ & 0.08 & 0.06 \\
\hline 49 & 1536 & 1505.0 & Eugenol acetate & 3.05 & 0.04 & - & - \\
\hline 50 & 1564 & 1539.7 & trans-Nerolidol & $\operatorname{tr}$ & - & $\operatorname{tr}$ & - \\
\hline 51 & 1574 & 1557.1 & Germacrene-D-4-ol & 0.05 & - & - & $\operatorname{tr}$ \\
\hline 52 & 1581 & 1565.5 & Caryophyllene oxide & 0.15 & 0.18 & 0.22 & 0.27 \\
\hline 53 & 1627 & 1595.5 & 1-epi-Cubenol & $\operatorname{tr}$ & $\operatorname{tr}$ & $\operatorname{tr}$ & $\operatorname{tr}$ \\
\hline 54 & 1641 & 1621.0 & $\tau$-Cadinol (epi- $\alpha-$-Cadinol) & 0.28 & 0.21 & 0.20 & 0.19 \\
\hline 55 & 1653 & 1634.9 & $\alpha$-Cadinol & 0.13 & 0.07 & 0.08 & 0.07 \\
\hline \multirow[t]{2}{*}{56} & 1686 & 1661.8 & $\alpha$-epi-Bisabolol & 1.92 & 2.00 & 1.60 & 1.54 \\
\hline & & & Total: & 98.23 & 97.84 & 96.88 & 96.57 \\
\hline
\end{tabular}

$\mathrm{n}=3 ; \operatorname{tr}<0,02 \%$; (-) - not present; KIL - Kovats (retention) index - literature data; KIE - Kovats (retention) index experimentally determined (AMDIS) 


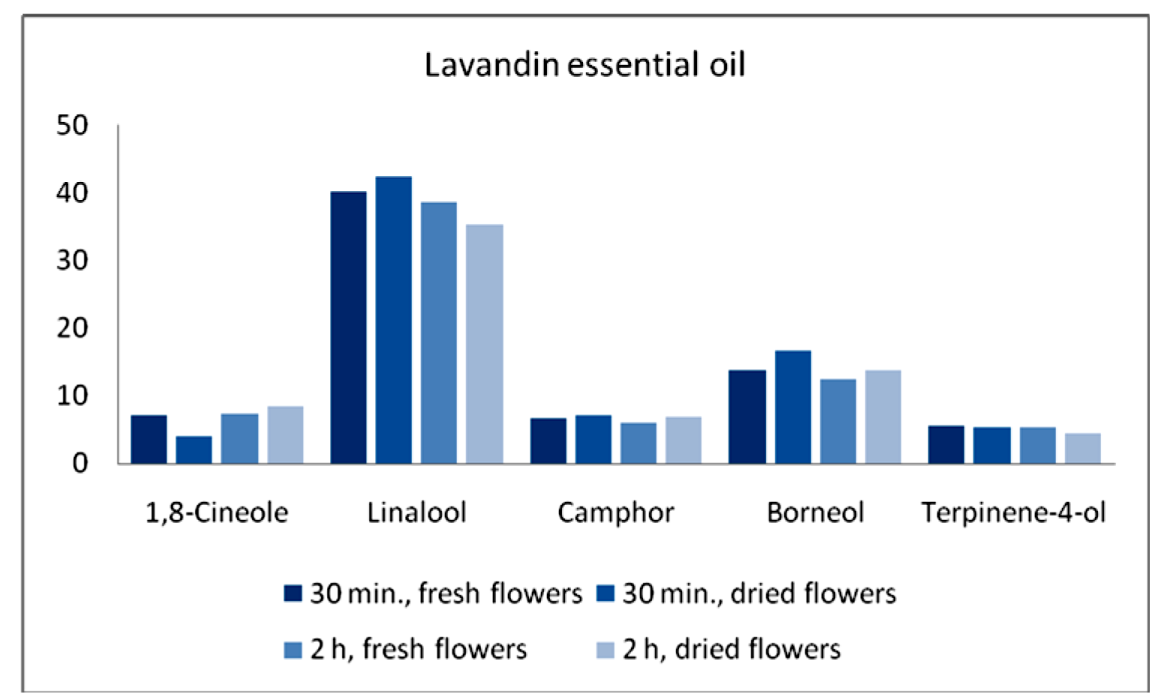

Fig. 1. The content of the main compounds in lavandin essential oil after 30 minutes and 2 hours distillation of fresh or dried lavandin flowers.

cedures showed insignificant variance in essential oil composition and the main constituents (linalool, borneol, 1,8cineole, camphor and terpinene-4-ol) content (Fig. 1).

At the same time, there were significant differences in the essential oil composition of tested lavandin compared to various essential oils originated from diverse regions world-wide (Table 2). Higher amounts of borneol were found in our lavandin oils than spike lavender oil that shows high level of linalool, 1,8-cineole and camphor and very low level of linalyl acetate (Table 1 and 2). Analyzed lavandin essential oils were more similar to the spike lavender oil than to oils of lavandin cultivars (var. "grosso" and var. "abrial"). This findings correlate with the
Renaud's report for the essential oil composition of 10 cultivars of lavandin and lavender, including $L$. x intermedia varieties stating that lavandin "grosso" oil has the highest amount of camphor (8.1\%) and low amount of borneol (Renaud et al., 2001).

It is worth to be mentioned that L. $x$ intermedia ( $L$. angustifolia $x$ L. latifolia) is a hybrid different from L. $x$ hybrida Balb. ex Ging. (L. dendata $x$ L. latifolia) that produces essential oil with different chemical composition with 1,8-cineole (up to $33.5 \%$ ) and camphor (up to $12.4 \%$ ) as major constituents (Tucker et al., 1993). On the other hand, Chu and Kemper used L. $x$ intermedia as a synonym for $L$. $x$ hybrida Reverchon or L. $x$ hybrida Burnamii (lavandin,

Table 2. The chemical composition of various lavender and lavandin oils (\%) (according to International standards)*

\begin{tabular}{lcccc}
\hline \hline Constituent & $\begin{array}{c}\text { L. angustifolia } \\
\text { Lavender }\end{array}$ & $\begin{array}{c}\text { L. intermedia } \\
\text { Lavandin "Grosso" }\end{array}$ & $\begin{array}{c}\text { L. intermedia } \\
\text { Lavandin "Abrial” }\end{array}$ & $\begin{array}{c}\text { L. latifolia } \\
\text { Spike lavender }\end{array}$ \\
\hline Linalool & $25-38$ & $24-35$ & $26-38$ & $34-50$ \\
Linalyl acetate & $25-45$ & $28-38$ & $20-29$ & $<1.6$ \\
$1,8-$ Cineole & $1-2$ & $4-7$ & $6-11$ & $16-39$ \\
$\beta$-Caryophyllene & $3-12$ & - & - & - \\
Limonene & $<1.0$ & $0.5-1.5$ & $0.5-1.5$ & $0.5-3$ \\
Terpinene-4-ol & $2-6$ & $1.5-5$ & $0.3-1$ & - \\
$\beta$-Ocimene & $2.5-6$ & $0.5-1.5$ & $1.5-7$ & - \\
Lavandulyl acetate & $3.4-6.2$ & $1.5-3$ & $1-2$ & - \\
Lavandulol & $>0.1$ & $0.2-0.8$ & $0.4-1.2$ & - \\
$\alpha-$ Terpineol & $<2$ & - & - & $0.2-2$ \\
Camphor & $0.5-1$ & $6-8$ & $7-11$ & $10-20$ \\
trans- $\alpha-B i s a b o l e n$ & - & - & - & $0.4-2.5$ \\
Borneol & - & $1.5-3$ & $1.5-3.5$ & - \\
Pinene & - & - & - & $1-3$ \\
\hline
\end{tabular}

*data published by MacTavish and Harris, 2002 
a hybrid of L. angustifolia $x$ L. latifolia), different species from L. $x$ hybrida Balb. ex Ging. (L. dendata $x$ L. latifolia) (Chu and Kemper, 2001). Anyhow, the chemical composition of analyzed lavandin oils could not met the international standard requirements for this oil.

Wesołowska stated that the time of distillation had a significant influence on the content of lavender oil constituents (Wesołowska et al., 2010). Zhekova and Nedkov pointed out that there are divided opinions about variability of the content of the main compounds in lavender oil during the distillation process. For instance, linalyl acetate, compound used for quality assessment compound of lavender oil, could be found in large quantities in the first 15 minutes of the distillation process. The same authors reported that highest oil yield from true lavender was gained within the first 15 minutes of the distillation. The quantity of linalyl acetate was constantly increased during entire 30 minutes and the oils separate between 15 and 30 minute possessed the best smell performance. For the other varieties it was indicated that during the process of distillation the amount of linalyl acetate, linalool and $\beta$-ocimene had declined. It was also noticed that the undesirable components for the smell of lavender oil, such as borneol and terpinene-4-ol, had greater content than before (Zhekova and Nedkov, 2010). Our results showed that borneol was present in high amount in the analyzed lavandin oils in all experimental cases (12.28-16.68\%) and opposite to above findings decreased with prolonged distillation of $2 \mathrm{~h}$. The amount of the undesirable monoterpene alcohol, terpinene4-ol was almost constant in all experimental conditions (4.44-5.62\%).

Commercially available lavender and lavandin essential oils are produced by distillation of freshly harvested plant material (flowering tops in full blossom). Distillation process is usually carefully designed as it can increase or reduce the value of the oil (lavender production, www. nda.agric.za/docs/brochures/essoilslavender.pdf). The duration, pressure, temperature and the average speed of distillation are factors that influence the essential oil quality. On the other hand, for research and experimental purposes, the essential oils are isolated in Clevenger type apparatus often from dried plant material and then analyzed by GC-MS (Ihsan, 2008; Wesolowska et al., 2010; Azar et al., 2011; Najafian et al., 2012; Shafaghat et al., 2012). Some authors compared the essential oil composition of oils obtained from fresh and dried lavender and found significant similarities in the oils' composition. Thus, the percentages of 1,8-cineole, linalool, borneol, camphor and linalyl acetate in essential oil from fresh lavender were $18.9 \%, 34.2 \%$, $12.1 \%, 4.6 \%$ and $3.1 \%$, respectively and were almost identical in the oil obtained from dried lavender $(20.3 \%, 33.0 \%$, $11.0 \%, 4.7 \%$ and $3.6 \%$ for 1,8 -cineole, linalool, borneol, camphor and linalyl acetate, respectively) (Ihsan, 2008).

The obtained results showed that drying of the lavandin inconsiderably influenced the essential oil composition and the whole character of the lavandin oil remained al- most unaffected (Fig. 1). This finding are in accordance with data published previously for lavender oil (Ihsan, 2008).

\section{Conclusion}

Essential oil composition of cultivated lavandin ( $L . x$ intermedia) from Republic of Macedonia, analyzed by $\mathrm{GC} /$ FID/MS, showed presence of fifty-six compounds representing $96.57 \%$ to $98.23 \%$ of the total oil. The main identified constituents of the oil were linalool (35.23-42.24\%), borneol (12.28-16.68\%), 1,8-cineole (3.99-8.42\%), camphor (5.96-7.04\%) and terpinene-4-ol (4.44-5.62\%), while linalyl acetate was present in very low amounts (1.53$2.42 \%$ ). Regardless the duration of the distillation process ( $30 \mathrm{~min}$ and $2 \mathrm{hrs)}$ and differences in the characteristics of plant material (fresh or dried flowering tops), the isolated lavandin oils did not show significant differences in their chemical composition

The chemical composition of analyzed lavandin oils did not comply with the international standard requirements.

\section{References}

Azar, P.A., Torabbeigi, M., Sharifan, A., Tehrani, M.S., 2011. Chemical composition and antibacterial activity of the essential oil of Lavandula angustofolia isolated by solvent free microwave assisted extraction and hydrodistillation, J. Food Biosci. Technol. 1, 19-24.

Ballabani, V., Tagnolini, M., Chiavarini, M., Impicciatore, M., Bruni, R., Ianchi, A., Barocelli, E., 2004. Novel antiplatelet and antitrombotic activities of essential oil from Lavandula hybrida Reverchon "grosso", Phytomedicine 11, 596-601.

Baydar, H., Kineci, S., 2009. Scent composition of essential oil, concrete, absolute and hydrosol from Lavandin (Lavandula $x$ intermedia Emeric ex Loisel.). J. Essent. Oil - bearing Plants 12 (2), 131-136.

Boeckelmann, A., 2008. Monoterpene production and regulation in lavenders (Lavandula angustifolia and Lavandula $x$ intermedia). Available at: http://hdl.handle.net/2429/2804

Cavanagh, H.M.A., Wilkinson, J.M., 2002. Biological activities of lavender essential oil. Phytother. Res. 16, 301-308.

Chu, C.J., Kemper, K.J., 2001. Lavender (Lavandula spp.), The Longwood Herbal Task Force

(http://www.mcp.edu/herbal/) and The Center for Holistic Pediatric Education and Research

(http://www.childrenshospital.org/holistic/). Available at: http:// www.longwoodherbal.org/lavender/lavender.pdf

Economou, K.D., Oreopoulou, V., Thomopoulus, C.D., 1991. Antioxidant activity of some plant extracts of the family Labiatae. J. Am. Oil Chem. Soc. 68, 109-115.

European Pharmacopeia 7.0, 2010. Council of Europe, Strasbourg, France. 1163-1164.

Gamez, M.J., Jimenez, J., Mavarro, C., Zarzuelo, A., 1990. Study of the essential oil of Lavandula dentate L. Pharmazie 45, 69-76.

Gilani, A.H., Aziz, N., Khan, M.A., Shaheen, F., Jabeen, Q., Siddidui, B.S., Herzig, J.W., 2000. Ethnopharmacological evaluation of the anticonvulsant, sedative and antispasmodic 
activities of Lavandulae stoechas L. J. Ethnopharmacol. 71, 161-167.

Ihsan, S.A., 2008. Essential oil composition of Lavandula officinalis L. grown in Jordan. Journal of Kerbala University 6, 209-212.

Guillen, M.D., Cabo, N., Burillo, J., 1996. Characterization of the essential oils of some cultivated aromatic plants of industrial interest. J. Sci. Food Agric. 70, 359-363.

Kalemba, D., Kunicka, A., 2003. Antibacterial and antifungal properties of essential oils. Curr. Med. Chem. 10, 12411253

Kim, N.S., Lee, D.S., 2002. Comparison of different extraction methods for analysis of fragrances from Lavandula species by gas chromatography-mass spectrometry. J. Chromatogr. 982, 31-47.

Kustrak, D., Besic, J., 1975. Aetheroleum Lavandulae and aetheroleum Lavandulae hybridae in Pharmacopeia Jugoslavia III. Pharmaceutica Acta Helvetiae 50, 373-378.

Lavender production, Essential oil crops. 2012. Available at: http://www.nda.agric.za/docs/brochures/essoilslavender.pdf

Lehrner, J., Marwincski, G., Lehr, S., Deecke L., 2005. Ambient odors of orange and lavender reduce anxiety mood in a dental office. Physiology and Behavior. 86, 92-95.

Lis-Balchin, M., Hart, S., 1999. Studies of the mode action of the essential oil of lavender (Lavandula angustifolia). Phytother. Res. 13, 540-543.

Louis, M., Kowalski, S.D., 2002. Use of aromatherapy with hospice patients to decrease pain, anxiety and depression and to promote an increased sense of well-being. Am. J. Hospice Palliative Care 19, 381-386.

MacTavish, H., Harris, D., 2002. A case study comparing nonUK lavender/lavandin production and peppermint/spearmint with UK production techniques and costs, ADAS Consulting Ltd. Available at: http://www.uicnmed.org/nabp/web/ documents/Essential\%20oils\%20study\%20-\%20UK.pdf

Najafian, S., Rowshan, V., Tarakemeh, A., 2012. Comparing essential oil composition and essential oil yield of Rosmarinus officinalis and Lavandula angustifolia before and full flowering stages. Int. J. Appl. Biol. and Pharm. Tech. 3, 212-218.

Paul, J.P., Brophy, J.J., Goldsack, R.J., Fomtaniella, B., 2004. Analysis of volatile compounds of Lavandula canariensis
(L.) Mill., a Canary Islands endemic species, growing in Australia. Biochem. Syst. Ecol. 32, 55-62.

Peterson, L., 2002. The Australian lavender industry. A review of oil production and related products, Rural Industries Research and Development Corporation. Australian Government. RIRDC publication No. 02-052.

Pitman, V., 2004. Aromatherapy: a practical approach. Nelson Thornes, pp. 111.

Porter, N. G., Shaw, M. L., Hurndell, L. C., 1982. Preliminary studies of Lavender as an essential oil crop for New Zeland. New Zeland J. Agric. Res. 25, 389-394. Avalable at: http:// www.tandfonline.com/doi/abs/10.1080/00288233.1982.104 17902\#preview

Renaud, E.N.C., Charles, D.J., Simon, J.E., 2001. Essential oil quantity and composition from 10 cultivars of organically grown lavender and lavandin. J. Essent. Oil Res. 13(4), 269273.

Sabara, D., Kunicka-Styczynska, A., 2009. Lavender oil flavoring or active cosmetic ingredients? Food Chem. Biotech. 73, 33-41.

Sell, Ch., 2006. The chemistry of fragrances. From perfumer to consumer, $2^{\text {nd }}$ edition. RSC Publishing, pp. 43.

Shafaghat, A., Salimi, F., Amani-Hooshyar, V., 2012. A phytochemical and antimicrobial activity of Lavandula officinalis leaves and stems against some pathogenic microorganisms. J. Med. Plant Res. 6, 455-460.

Tucker, A.O., Maciarello, M.J., Angell, S., Espaillat, J.R., French. E.C., 1993. The essential oil of L. $x$ hybrida Balb. ex Ging., a distinct hybrid from L. $x$ heterophylla Poir. (Labiate). J. Essen. Oil Res. 5, 443-445.

Wesolowska, A., Jadczak, D., Grzeszczuk, M., 2010. Influence of distillation time on the content and composition of essential oil isolated from lavender (Lavandula angustifolia Mill.). Herba Polonica 56, 24-36. Available at: http://www. herbapolonica.pl/magazines-files/9535420-art.3-3-2010.pdf

Wogiatzi, E., Papachatzis, A., Kalorizou, H., Tzalahani, A., 2011. Analysis of Lavandula hybrid essential oils growing in Greece, University of Craiova 16, 488-491. Available at: http://www.anucraiova.3x.ro/cont/2011/Wogiatzi.pdf

Zhekova, G., Nedkov, N., 2010. Quantitative changes in major components of lavender oil during the distillation process. Agric. Sci. Technol. 2, 26-28. 


\title{
Резиме
}

\section{Влијание на времетраењето на дестилацијата на свежи и на суви цветови врз составот на етеричното масло од култивиран лавандин од Република Македонија}

\author{
Марија Карапанџова*, Ивана Цветковиќ, Ѓшше Стефков, Влатко Стоименов, \\ Мартин Црвенов, Светлана Кулеванова \\ Институт за Фармакогнозија, Фармацевтски Факултет, Универзитет „, Св. Кирил и Методиј“, Скопје, \\ Република Македонија
}

Клучни зборови: Lavandula intermedia, Lamiaceae, GC/FID/MS, времетраење на хидродестилација, време на сушење.

Главната цел на оваа студија беше да се анализира составот на етеричното масло од култивиран лавандин (Lavandula x intermedia Emeric ex Loisel., Lamiaceae) во Република Македонија и да се процени влијанието на сушењето на растителниот материјал и времетраењето на дестилацијата врз составот на маслото. Со хидродестилација на свежо набрани и исушени цветови на лавандин во Клевенџер апарат беа добиени 4 различни етерични масла во зависност од времето на дестилацијата (30 минути и 2 часа). Со GC/FID/MS анализа беа идентификувани вкупно 56 компоненти што претставува 96,57\% - 98,23\% од вкупното масло. Доминанти компоненти во анализираните етерични масла беа: линалол (од 35,23\% до 42,24\%), борнеол (од 12,28\% до 16,68\%) и терпинен4-ол (од 4,44\% до 5,62\%). Содржината на 1,8-цинеол варираше од 3,99\% до 8,42\%, додека содржината на камфор беше помеѓу $5,96 \%$ и 7,04\%. Линалил ацетат беше присутен во количини од 1,26\% до 3,21\%. Неочекувано, времетраењето на дестилација незначително влијаеше на составот на етеричните масла. Беа забележани неколку разлики во етеричните масла добиени со 30 минутна дестилација, главно во содржината на борнеол (13,71\% во масло дестилирано од свежи цветови и $16,68 \%$ во масло од суви цветови), додека содржината на другите соединенија беше речиси непроменета. Независно, хемискиот состав на изолираните етерични масла не е во согласност со меѓународните стандарди барања за составот на етеричните масла од лавандин. 